\title{
Basic fibroblast growth factor may improve devascularized sternal healing( Abstract_要旨)
}

\author{
AUTHOR(S): \\ Iwakura, Atsushi
}

\section{CITATION:}

Iwakura, Atsushi. Basic fibroblast growth factor may improve devascularized sternal healing. 京都大学, 2001, 博士(医学)

ISSUE DATE:

2001-03-23

URL:

http://hdl.handle.net/2433/150532

RIGHT: 


$\begin{array}{llll}\text { 氏 } & \text { 名 } & \text { 岩 } & \text { 倉 } \\ \text { 学位(尃攻分野) } & \text { 博 } & \text { 士 (医 } & \text { 学) } \\ \text { 学位記番号 } & \text { 医 博 第 } 2336 \text { 号 }\end{array}$

学位授与の日付。平成 13 年 3 月 23 日

学位授与の要件、学位規則第 4 条第 1 項該 当

研究科・専攻医学研究科外科系専攻

学位論文題目 Basic fibroblast growth factor may improve devascularized sternal healing

（塩基性線維芽細胞增殖因子による虚血胸骨再生）

論文調查委員 教授中村孝志教授開 祐司教授米田正始

論文 内容 の 要旨

冠動脈バイパス術に抢ける内胸動脈の使用はその良好な長期開存率により術後遠隔期の患者生命予後を改善するとされ， 現在最も高頻度に用いられている。しかし, 特に西側内胸動脈を冠動脈へのバイパス血管に使用した場合, 胸骨への血液供 給が途絶され，正中切開後の胸骨の治瘾遅延もしくは治瘾障害が生じる。これらの合併症は患者の入院期間を延長するだけ でなく，術後の QOLにも大きく影響する。また，胸骨治瘾障害から一旦前絣隔洞炎を合併すると患者の生命子後を大きく 左右する。一方, 強力な血管新生因子である塩基性線維芽細胞增殖因子（basic fibroblast growth factor: bFGF）は骨新生 作用も有することが明らかにされた。本研究では bFGF が血管および骨新生作用により两側内胸動脈採取後の虚血に陥う た胸骨の治癋を促進するかどうかを検討した。

体重 300 350g のウィスターラット15匹を用い，挿管下で全例に胸骨正中切開を行った後，以下の 3 群に分類した（各

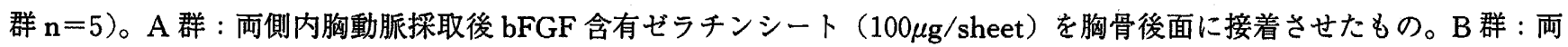
側内胸動脈採取のみを行ったもの。C 群 : 両側内胸動脈採取せず。術後 4 週後に血管新生及び骨再生について検討した。ゼ ラチンシートは等電点4.9のアルカリ処理ゼラチンをグルタルアルデヒドにて化学架橋することによって作製し，その含水 率は $90.3 \%$ あった。

非接触型レーザードップラー血流計を用いた胸骨周囲の組織血流は術後 4 週目では術前值に比較して A 群 : 114.0 12.3 ,

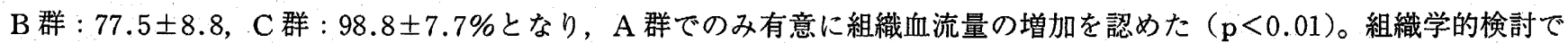

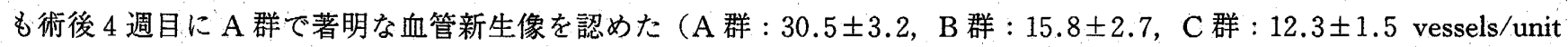
area, $\mathrm{p}<0.01)$ 。骨再生については A 群で術後 2 週目より骨再生が始まり，4 週目では組織学上ほぼ完全な軟骨内骨化を認 めたのに対し，B 群と C 群では軟骨内骨化は一部のみであった。さらにDual Energy X-ray Absorptometry による胸骨の

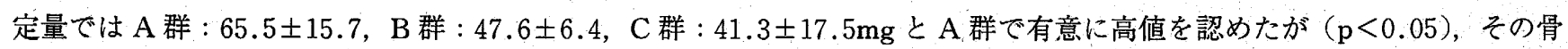
密度には 3 群間で有意差は認められなかった（A 群 : $51.1 \pm 8.1, B$ 群 : $50.0 \pm 6.1, C$ 群 : $43.7 \pm 8.4 \mathrm{mg} / \mathrm{mm}^{2}$ )。また, 骨 リモデリングの指標の一つである osteoclast index は $\mathrm{A}$ 群でのみ再生骨領域と再生骨及び軟骨の境界領域の両方で増加して Wた。

以上によりラット両側内胸動脈採取モデルに扔いて bFGF 含有ゼラチンジートは胸骨周囲の虚血を血管新生により改善 するとともに正常な骨再生を促進することが明らかとなった。本研究は胸骨正中切開による心臟手術後の胸骨合併症を軽隇 するための全く新しい再生医学的アプローチであり，これにより開心術後の社会復㸟の促進と高齢者, 糖尿病などのハイり スク患者に対する冠動脈バイパス術において両側内胸動脈の使用の適応が拡大される可能性が示唆された。

論文審查の結 果 の 要 旨

冠動脈バイパス術における内胸動脈の使用はその良好な長期開存率により術後遠隔期の患者生命予後を己寋するが, 胸骨 
への血液供給示途絶され，正中切開後の胸骨の治癒障害が生じる。これは患者の入院期間を延長するだけでなく，術後の Quality of Lifeにも大きく影響する。そこで，強力な血管新生及び骨新生作用を有する塩基性線維芽細胞增殖因子 (basic fibroblast growth factor : bFGF) が両側内胸動脈採取後の虚血に陥った胸骨の治癒を促進するかどうかを検討した。

ラットを用い胸骨正中切開後の両側内胸動脈採取モデルを作製し，bFGF 含有ゼラチンシート）を胸骨後面に接着させ， 術後 4 週後の血管新生及び骨再生について検討した。bFGF 含有ゼラチンシート使用により胸骨周囲には血管新生を認める とともに組織血流量の増加を認めた。骨再生についても bFGF 含有ゼラチンシート使用することで術後早期から正常な骨 再生が始まるとともに骨りモデリングが促進されることにより，胸骨治癒が加速されることが判明した。

以上の研究は胸骨正中切開による心臓手術後の胸骨合併症を軽減するために增殖因子を用いた全く新しい再生医学的アプ ローチを示したものであり，開心術後の社会復帰の促進と高齢者, 糖尿病などのハイリスク患者に対する冠動脈バイパス術 において両側内胸動脈の使用の適応が拡大されることに寄与するところが多い。

したがって本論文は博士 (医学) の学位論文として価値のあるものと認める。

なお，本学位授与申請者は，平成13年 2 月 14 日実施の論文内容とそれに関連した試問を受け，合格と認められたものであ る。 